\title{
Effect of ambient levels of smoke and sulphur dioxide on the health of a national sample of 23 year old subjects in 1981
}

\author{
Jane F Scarlett, Joanne M Griffiths, David P Strachan, H Ross Anderson
}

\begin{abstract}
Background - There is concern that, despite the fall in air pollution levels since the 1950s, there may still be adverse effects at current levels. A study was carried out to investigate the association between air pollution and respiratory symptoms in 23 year old subjects in 1981 .
\end{abstract}

Methods - Data on cough, phlegm, and wheeze were available on 11552 members of the 1958 national birth cohort. Counties in the UK were ranked by annual average level of black smoke and sulphur dioxide $\left(\mathrm{SO}_{2}\right)$, and then divided into five groups. The subject's county of residence determined their categorisation of pollution exposure. The association between air pollution exposure and respiratory symptoms was examined by logistic regression, adjusting for social class, sex, and smoking. Results - The ranges of the air pollution groups were $2 \cdot 0-13 \cdot 0,13 \cdot 1-18 \cdot 7,19 \cdot 6-20 \cdot 8$, $21 \cdot 0-25 \cdot 8$, and $26 \cdot 1-55 \cdot 1 \mu \mathrm{g} / \mathrm{m}^{3}$ for black smoke, and $7 \cdot 0-36 \cdot 4,36 \cdot 7-42 \cdot 7,43 \cdot 0-50 \cdot 5$, $52 \cdot 0-59 \cdot 3$, and $60 \cdot 9-87 \cdot 7 \mu \mathrm{g} / \mathrm{m}^{3}$ for $\mathrm{SO}_{2}$. The overall prevalences of cough, phlegm, wheezing since age 16 , and wheezing in the past year were $13 \cdot 3 \%, 10 \cdot 3 \%, 9 \cdot 4 \%$, and $4 \cdot 4 \%$, respectively. Phlegm symptoms increased with increasing smoke levels with evidence of a plateau. Cough and wheeze were not associated with black smoke; no symptom was associated with $\mathrm{SO}_{2}$. In the subgroup with wheeze at ages 16-23 there was no effect of smoke level on phlegm.

Conclusions - Low ambient levels of black smoke were associated with decreased prevalence of phlegm symptoms in young adults in the UK in 1981. The effect was evident below the current EC guideline of 34-51 $\mu \mathrm{g} / \mathrm{m}^{3}$ annual black smoke. In 1991 the annual mean smoke level for each county ranged from 3.4 to $26 \cdot 5 \mu \mathrm{g} / \mathrm{m}^{3}$, spanning all but the last exposure group used here. This is consistent with the existence of adverse and possibly chronic effects at current levels.

(Thorax 1995;50:764-768)

Keywords: phlegm, air pollution, smoke.

The London smog of 1952 , associated with very high levels of sulphur dioxide $\left(\mathrm{SO}_{2}\right)$ and black smoke, is known to have caused around 4000 deaths. ${ }^{1}$ This showed convincingly that episodes of air pollution could have important effects on mortality and led to the Clean Air Act of 1956. The Clean Air Act dramatically reduced emissions and ambient levels of smoke and $\mathrm{SO}_{2}$ from coal combustion. ${ }^{2}$ The association between air pollution and mortality ${ }^{3}$ and morbidity from bronchitis ${ }^{4}$ persisted in the 1960 s, but studies from the 1970 s found no association. ${ }^{4-9}$ It was generally believed that air pollution had ceased to be an important public health problem.

There has been a resurgence of concern about the possible effects of pollution, especially that from motor vehicles, which now produce as much particulate pollution as all other sources and account for the majority of oxides of nitrogen. ${ }^{2}$ Using more sophisticated statistical techniques for analysing time series data, a number of studies - mainly from the USA but also from Europe - have demonstrated effects on daily mortality, admissions, symptoms, and lung function at ambient levels below current national and international standards. ${ }^{10}$ In the one reported study from the UK associations between hospital admissions and smoke and $\mathrm{SO}_{2}$ levels were reported within current guideline levels. ${ }^{11}$ Concerns about the health effects of air pollution have also been fuelled by concern about an increase in asthma and other atopic diseases.

Most evidence relates to short term effects of air pollution, but there is also evidence from the USA that chronic effects may occur. ${ }^{12-15}$ An opportunity to study the chronic effects of air pollution in the UK using a cross sectional analysis is provided by respiratory data from the 1958 national birth cohort who were surveyed in 1981 at the age of 23. Data about the potential confounding factors of smoking and social class are also available. Although average levels of smoke and $\mathrm{SO}_{2}$ were higher in 1981 than at present, the range of exposures at county level overlaps with the current range and falls within EC guideline levels. Thus, the results will be of relevance to the present day situation.

\section{Methods}

STUDY SUBJECTS AND HEALTH DATA

The study used information from 11552 subjects aged 23 years who were interviewed in 1981 as part of the National Childhood Development Survey (NCDS, a cohort of people born between 3 and 9 March 1958). Subjects were asked two questions on asthma/wheezy bronchitis: (1) have you suffered from asthma 
or wheezy bronchitis since your 16th birthday? (2) have you suffered from asthma or wheezy bronchitis in the past 12 months?; two questions on cough: (1) do you usually cough first thing in the morning in winter? (2) do you usually cough during the day or night during the winter?; two questions on phlegm: (1) do you usually bring up phlegm first thing in the morning in winter? (2) do you usually bring up phlegm during the day or night during winter?; and three questions on smoking: (1) have you ever smoked a cigarette, a cigar or a pipe? (2) do you smoke cigarettes at all nowadays? (3) have you ever smoked cigarettes regularly?

Subjects were classed as having cough symptoms if they answered yes to either of the cough questions and as having phlegm symptoms if they answered yes to either of the phlegm questions. Smokers were classified as "current", "ex", "experimental", or "never". Exsmokers were those who used to smoke regularly whilst experimental smokers had smoked but not regularly. Subjects were grouped into classes I and II, IIINM, IIIM, IV and V using the Registrar General's classification of social class. The most detailed geographical information available was subjects' counties of residence. Only subjects with complete data on all relevant factors were included in each analysis which has led to different denominators for each analysis.

\section{POLLUTION DATA}

Pollution data were obtained from the Air Pollution Division of Warren Spring Laboratory and consisted of the annual mean, median, and 98th percentile measurements for smoke and $\mathrm{SO}_{2}$ for all monitoring sites active in 1981 . Black smoke was measured using the British Standard reflectance method and $\mathrm{SO}_{2}$ using peroxide samplers. ${ }^{2}$ Monitoring stations were excluded if values were missing for more than 14 daily measurements in the year, or for seven consecutive days. In addition, monitoring stations at purely industrial sites were excluded as these may not reflect the air pollution exposure of the population.

\section{ANALYSIS}

The smallest geographical unit at which subjects and pollution measures could be matched was at county level. Smoke and $\mathrm{SO}_{2}$ pollution measures for each county were calculated as the average of annual mean levels for all eligible

Table 1 Prevalence of symptoms by smoking status (number (\%) of subjects)

\begin{tabular}{lllll}
\hline & $\begin{array}{l}\text { Asthma/wheeze } \\
\text { since 16 }\end{array}$ & $\begin{array}{l}\text { Asthma/wheeze } \\
\text { at 23 }\end{array}$ & Cough & Phlegm \\
\hline Current smoker & 528 & 225 & 1161 & 807 \\
$(\mathrm{n}=4628)$ & $(11 \cdot 4)$ & $(4 \cdot 9)$ & $(25 \cdot 1)$ & $(17 \cdot 4)$ \\
Ex-smoker & 118 & 55 & 63 & 57 \\
$(\mathrm{n}=1128)$ & $(10 \cdot 5)$ & $(4 \cdot 9)$ & $(5.6)$ & $(5 \cdot 0)$ \\
Pipe/tried & 157 & $(3 \cdot 7)$ & 134 & 117 \\
$(\mathrm{n}=2142)$ & $(7 \cdot 3)$ & 131 & $(6 \cdot 3)$ & $(5 \cdot 5)$ \\
Never smoked & 275 & $(3 \cdot 7)$ & 197 & 191 \\
$(\mathrm{n}=3536)$ & $(7 \cdot 8)$ & 490 & $(5 \cdot 6)$ & $(5 \cdot 4)$ \\
Total $(\mathrm{n}=11434)$ & 1078 & $\mathrm{p}=0 \cdot 02$ & 1555 & 1172 \\
$\chi^{2}$ & $\mathrm{p}<0 \cdot 01$ & & $\mathrm{p}<0 \cdot 01$ & $\mathrm{p}<0 \cdot 01$ \\
\hline
\end{tabular}

monitors within the county. Counties were then ranked by their mean pollution levels and arranged into five exposure groups with as near equal numbers of subjects in each group as possible.

Analyses of the effect of county pollution levels on county sympiom prevalences could not be carried out for several reasons. Firstly, allocating individual pollution measures to each subject leads to an analysis of the effect of living in each county rather than an analysis of the effect of exposure to ambient pollution levels. By using exposure groups people from different counties are in the same group, and thus the effects of potential confounding factors such as climate or geographical location are reduced. Secondly, allocating the mean county value as a measure of pollution exposure implies a degree of precision in the exposure estimate which does not exist. It is more certain that, within exposure group 1, despite individual variation in exposure, individuals have greater exposure to pollution than those within group 2 . Thirdly, simple correlations between the prevalences of symptoms by county and the mean pollution levels were inappropriate because some counties had few subjects $(<10)$, and thus symptom prevalences were either zero or large. Grouping subjects into five groups meant all available information could be included in the analysis.

Smoke and $\mathrm{SO}_{2}$ were ranked and grouped separately, hence subjects may be in a different exposure group for each of the two pollutants. A combined smoke and $\mathrm{SO}_{2}$ level for the 50 counties with both measurements was calculated by ranking counties by their smoke levels and $\mathrm{SO}_{2}$ levels, and adding the ranks.

The odds ratio of each of the four respiratory symptoms was computed using logistic regression models within which the potential confounding factors of smoking, social class, and sex were included. In the first instance a test for homogeneity across the pollution groups was performed, and this was followed by a test for trend where there was some evidence of a trend on inspection. The trend analyses used the median value of pollution in each exposure group as a covariate.

\section{Results}

A total of 11552 subjects was included in the analysis. Smoke data were missing for $118 ; \mathrm{SO}_{2}$ data for 36; social class data for 2366; smoking data for six; gender data for two; phlegm data for nine; cough data for six; and data on asthma at the age of 23 and asthma since the age of 16 for one. The number of subjects used in each analysis is shown in the tables.

The prevalence of asthma since age 16 was $9.4 \%$; asthma or wheezing in the past year, $4.4 \%$; cough, $13 \cdot 3 \%$; and phlegm, $10 \cdot 3 \%$. Prevalence of respiratory symptoms was strongly related to smoking (table 1) and cough and phlegm were also strongly related to social class (table 2).

Pollution measures were available for 54 counties after the exclusion criteria had been applied, 53 for smoke and 51 for $\mathrm{SO}_{2}$. There was variation in the ambient levels of smoke and 
Table 2 Prevalence of symptoms and smoking by social class (number (\%) of subjects)

\begin{tabular}{|c|c|c|c|c|c|}
\hline & $\begin{array}{l}\text { Asthma/wheeze } \\
\text { since } 16\end{array}$ & $\begin{array}{l}\text { Asthma/wheeze } \\
\text { at } 23\end{array}$ & Cough & Phlegm & $\begin{array}{l}\text { Current } \\
\text { smoker }\end{array}$ \\
\hline $\begin{array}{l}\text { Social class } \\
\text { I and II }(n=1766) \\
\text { Social class } \\
\text { IIINM }(n=3124) \\
\text { Social class } \\
\text { IIIM }(n=2244) \\
\text { Social class IV } \\
\text { and V }(n=1950) \\
\text { Total }(n=9084) \\
\chi^{2}\end{array}$ & $\begin{array}{l}162 \\
(9 \cdot 2) \\
299 \\
(9 \cdot 6) \\
219 \\
(9 \cdot 8) \\
196 \\
(10 \cdot 0) \\
876 \\
\text { NS }\end{array}$ & $\begin{array}{l}77 \\
(4 \cdot 4) \\
126 \\
(4 \cdot 0) \\
103 \\
(4 \cdot 6) \\
79 \\
(4 \cdot 0) \\
385 \\
\text { NS }\end{array}$ & $\begin{array}{l}175 \\
(9 \cdot 9) \\
326 \\
(10 \cdot 4) \\
401 \\
(17 \cdot 9) \\
406 \\
(20 \cdot 8) \\
1308 \\
\mathrm{p}<0 \cdot 01\end{array}$ & $\begin{array}{l}129 \\
(7 \cdot 3) \\
228 \\
(7 \cdot 3) \\
325 \\
(14 \cdot 5) \\
309 \\
(15 \cdot 8) \\
991 \\
\mathrm{p}<0 \cdot 01\end{array}$ & $\begin{array}{l}621 \\
(35 \cdot 2) \\
1123 \\
(35 \cdot 9) \\
1059 \\
(47 \cdot 2) \\
1106 \\
(56 \cdot 7) \\
3909 \\
\mathrm{p}<0 \cdot 01\end{array}$ \\
\hline
\end{tabular}

NS = not significant.

Table 3 Distribution of air pollution for the counties in 1981

\begin{tabular}{lllllll}
\hline & Mean & $S D$ & Median & Minimum & Maximum & Range \\
\hline Smoke $\left(\mu \mathrm{g} / \mathrm{m}^{3}\right)(53$ counties $)$ & $17 \cdot 9$ & $9 \cdot 20$ & $17 \cdot 0$ & $2 \cdot 0$ & $55 \cdot 1$ & $53 \cdot 1$ \\
$\mathrm{SO}_{2}\left(\mu \mathrm{g} / \mathrm{m}^{3}\right)(51$ counties $)$ & $42 \cdot 6$ & $15 \cdot 39$ & $41 \cdot 3$ & $7 \cdot 0$ & $87 \cdot 7$ & $80 \cdot 7$
\end{tabular}

$\mathrm{SO}_{2}$ across counties (smoke, range $2 \cdot 0-55 \cdot 1$ $\mu \mathrm{g} / \mathrm{m}^{3}$, mean $17 \cdot 9 \mu \mathrm{g} / \mathrm{m}^{3} ; \mathrm{SO}_{2}$, range $7 \cdot 0-87 \cdot 7$ $\mu \mathrm{g} / \mathrm{m}^{3}$, mean $42.6 \mu \mathrm{g} / \mathrm{m}^{3}$ ) (table 3 ). Smoke and $\mathrm{SO}_{2}$ were highly correlated $(r=0.61, \mathrm{p}<0.001)$. The levels for smoke and $\mathrm{SO}_{2}$ in each exposure group are shown in table 4 .

\section{RELATION BETWEEN POLLUTION LEVELS AND SYMPTOM PREVALENCE}

The prevalence of respiratory symptoms in each exposure group is shown in table 4 , and odds ratios in table 5 . The odds ratio for phlegm symptoms was different between different exposure groups $(p<0.01$, adjusted for smoking, sex, and social class) (table 4). This was highest in groups 3 and 4 , but fell again in group 5, which suggests a non-linear relationship. Because the relationship appeared to be nonlinear the log of the median smoke level in each exposure group was used as a covariate in the trend analysis. This gave evidence of a trend $(\mathrm{p}<0.05)$ (table 4) which implies that an increase in smoke exposure is associated with an increase in the prevalence of phlegm symptoms, but that this effect levels off at higher concentrations of smoke. There was no interaction between pollution and wheeze for increased phlegm production $\left(n=8961\right.$; unadjusted $\chi^{2}$ $7 \cdot 6$, df 4; adjusted $\chi^{2} 4 \cdot 9$, df 4 ).
There was some variation, although not statistically significant, in the odds ratio for cough symptoms across the smoke exposure groups. Asthma symptoms and smoke levels were not associated.

There was no evidence of variation in the odds ratios for any of the four respiratory symptoms across the $\mathrm{SO}_{2}$ exposure groups. There was no relationship between prevalence of current smoking and pollution levels.

The odds ratios for phlegm symptoms increased with increasing combined pollution exposure group, but this was not statistically significant. There was no association between the other three respiratory symptoms and combined pollution exposure.

When the analysis was restricted to those who had not changed county of residence between the ages of 16 and 23, the relationship was similar but the results were no longer significant.

\section{Discussion}

The pollution exposure measures used here are of ambient levels averaged over counties, but individual exposures will vary from these for a variety of reasons including distance from the monitor, time spent outside, level of physical activity, etc. Allocating the same exposure to

Table 4 Prevalence of respiratory symptoms by pollution exposure group (number (\%) of subjects)

\begin{tabular}{|c|c|c|c|c|c|c|c|c|c|c|c|}
\hline & \multicolumn{5}{|c|}{ Smoke exposure group } & & \multicolumn{5}{|c|}{$\mathrm{SO}_{2}$ exposure group } \\
\hline & $\begin{array}{l}\text { Asthmal } \\
\text { wheeze } \\
\text { since } 16\end{array}$ & $\begin{array}{l}\text { Asthmal } \\
\text { wheeze } \\
\text { at } 23\end{array}$ & Cough & Phlegm & $\begin{array}{l}\text { Current } \\
\text { smoker }\end{array}$ & & $\begin{array}{l}\text { Asthmal } \\
\text { wheeze } \\
\text { since } 16\end{array}$ & $\begin{array}{l}\text { Asthmal } \\
\text { wheeze } \\
\text { at } 23\end{array}$ & Cough & Phlegm & $\begin{array}{l}\text { Current } \\
\text { smoker }\end{array}$ \\
\hline $\begin{array}{l}\text { Smoke } 2 \cdot 0-13 \cdot 0 \mu \mathrm{g} / \mathrm{m}^{3} \\
\text { (subjects } \mathrm{n}=2245, \\
\text { counties } \mathrm{n}=18 \text { ) }\end{array}$ & $\begin{array}{l}212 \\
(9 \cdot 4)\end{array}$ & $\begin{array}{l}99 \\
(4 \cdot 4)\end{array}$ & $\begin{array}{l}274 \\
(12 \cdot 2)\end{array}$ & $\begin{array}{l}192 \\
(8 \cdot 6)\end{array}$ & $\begin{array}{l}891 \\
(39 \cdot 7)\end{array}$ & $\begin{array}{l}\mathrm{SO}_{2} 7 \cdot 0-36 \cdot 4 \mu \mathrm{g} / \mathrm{m}^{3} \\
\text { (subjects } \mathrm{n}=2162 \\
\text { counties } \mathrm{n}=18 \text { ) }\end{array}$ & $\begin{array}{l}199 \\
(9 \cdot 2)\end{array}$ & $\begin{array}{l}89 \\
(4 \cdot 1)\end{array}$ & $\begin{array}{l}288 \\
(13 \cdot 3)\end{array}$ & $\begin{array}{l}244 \\
(10 \cdot 4)\end{array}$ & $\begin{array}{l}843 \\
(39 \cdot 0)\end{array}$ \\
\hline $\begin{array}{l}\text { Smoke } 13 \cdot 1-18 \cdot 7 \mu \mathrm{g} / \mathrm{m}^{3} \\
\text { (subjects } \mathrm{n}=2150,\end{array}$ & $\begin{array}{l}209 \\
(9 \cdot 7)\end{array}$ & $\begin{array}{l}103 \\
(4 \cdot 8)\end{array}$ & $\begin{array}{l}310 \\
(14 \cdot 4)\end{array}$ & $\begin{array}{l}238 \\
(11 \cdot 1)\end{array}$ & $\begin{array}{l}856 \\
(39 \cdot 9)\end{array}$ & $\begin{array}{l}\mathrm{SO}_{2} 36 \cdot 7-42 \cdot 7 \mu \mathrm{\mu g} / \mathrm{m}^{3} \\
\text { (subjects } \mathrm{n}=2143 \text {, }\end{array}$ & $\begin{array}{l}208 \\
(9 \cdot 7)\end{array}$ & $\begin{array}{l}100 \\
(4 \cdot 7)\end{array}$ & $\begin{array}{l}330 \\
(15 \cdot 4)\end{array}$ & $\begin{array}{l}231 \\
(10 \cdot 8)\end{array}$ & $\begin{array}{l}894 \\
(41 \cdot 8)\end{array}$ \\
\hline $\begin{array}{l}\text { Smoke } 19 \cdot 6-20 \cdot 8 \mu \mathrm{g} / \mathrm{m}^{3} \\
(\text { subjects } \mathrm{n}=2285, \\
\text { counties } \mathrm{n}=4 \text { ) }\end{array}$ & $\begin{array}{l}231 \\
(10 \cdot 1)\end{array}$ & $\begin{array}{l}105 \\
(4 \cdot 6)\end{array}$ & $\begin{array}{l}283 \\
(12 \cdot 4)\end{array}$ & $\begin{array}{l}228 \\
(10 \cdot 0)\end{array}$ & $\begin{array}{l}910 \\
(39 \cdot 9)\end{array}$ & $\begin{array}{l}\mathrm{SO}_{2} 43 \cdot 0-50 \cdot 5 \mu \mathrm{g} / \mathrm{m}^{3} \\
\text { (subjects } \mathrm{n}=2428, \\
\text { counties } \mathrm{n}=12 \text { ) }\end{array}$ & $\begin{array}{l}229 \\
(9 \cdot 4)\end{array}$ & $\begin{array}{l}92 \\
(3 \cdot 8)\end{array}$ & $\begin{array}{l}311 \\
(12 \cdot 8)\end{array}$ & $\begin{array}{l}235 \\
(9 \cdot 7)\end{array}$ & $\begin{array}{l}954 \\
(39 \cdot 4)\end{array}$ \\
\hline $\begin{array}{l}\text { Smoke } 21 \cdot 0-25 \cdot 8 \mu \mathrm{g} / \mathrm{m}^{3} \\
\text { (subjects } \mathrm{n}=2610 ;^{*} \\
\text { counties } \mathrm{n}=7 \text { ) }\end{array}$ & $\begin{array}{l}236 \\
(9 \cdot 0)\end{array}$ & $\begin{array}{l}101 \\
(3 \cdot 9)\end{array}$ & $\begin{array}{l}388 \\
(14 \cdot 9)\end{array}$ & $\begin{array}{l}299 \\
(11 \cdot 5)\end{array}$ & $\begin{array}{l}1090 \\
(41 \cdot 8)\end{array}$ & $\begin{array}{l}\mathrm{SO}_{2} 52 \cdot 0-59 \cdot 3 \mu \mathrm{g} / \mathrm{m}^{3} \\
\text { (subjects } \mathrm{n}=1552, \\
\text { counties } \mathrm{n}=4 \text { ) }\end{array}$ & $\begin{array}{l}150 \\
(9 \cdot 7)\end{array}$ & $\begin{array}{l}75 \\
(4 \cdot 8)\end{array}$ & $\begin{array}{l}211 \\
(13 \cdot 6)\end{array}$ & $\begin{array}{l}166 \\
(10 \cdot 7)\end{array}$ & $\begin{array}{l}638 \\
(41 \cdot 1)\end{array}$ \\
\hline $\begin{array}{l}\text { Smoke } 26 \cdot 1-55 \cdot 1 \mu \mathrm{g} / \mathrm{m}^{3} \\
\text { (subjects } \mathrm{n}=2019, \\
\text { counties } \mathrm{n}=9 \text { ) }\end{array}$ & $\begin{array}{l}174 \\
(8 \cdot 7)\end{array}$ & $\begin{array}{l}77 \\
(3 \cdot 8)\end{array}$ & $\begin{array}{l}285 \\
(14 \cdot 2)\end{array}$ & $\begin{array}{l}207 \\
(10 \cdot 3)\end{array}$ & $\begin{array}{l}817 \\
(40 \cdot 6)\end{array}$ & 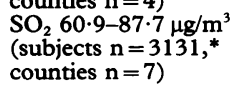 & $\begin{array}{l}289 \\
(9 \cdot 3)\end{array}$ & $\begin{array}{l}133 \\
(4 \cdot 3)\end{array}$ & $\begin{array}{l}410 \\
(13 \cdot 2)\end{array}$ & $\begin{array}{l}310 \\
(9 \cdot 9)\end{array}$ & $\begin{array}{l}1279 \\
(41 \cdot 0)\end{array}$ \\
\hline
\end{tabular}

* The large number in this group is due to Greater London which has 1550 subjects. 
Table 5 Respiratory symptoms by pollution exposure group

\begin{tabular}{|c|c|c|c|c|c|c|c|c|c|c|}
\hline \multicolumn{3}{|c|}{ Smoke exposure group $(n=8961)$} & \multicolumn{8}{|c|}{ Odds ratios for respiratory symptoms } \\
\hline$n$ & Range & Median & $\begin{array}{l}\text { Cough } \\
\text { Coun }\end{array}$ & $* *$ & $\begin{array}{l}\text { Phlegm } \\
*\end{array}$ & $* *$ & \multicolumn{2}{|c|}{ Wheeze at 23} & \multicolumn{2}{|c|}{ Wheeze since 16} \\
\hline $\begin{array}{l}1782 \\
1724 \\
1813 \\
2039 \\
1603 \\
\text { Test f } \\
\text { Test f } \\
\text { Test f }\end{array}$ & $\begin{array}{r}2 \cdot 0-13 \cdot 0 \\
13 \cdot 1-18 \cdot 7 \\
19 \cdot 6-20 \cdot 8 \\
21 \cdot 0-25 \cdot 8 \\
26 \cdot 1-55 \cdot 1 \\
\text { neity ( } \mathrm{p} \text { valu } \\
\text { and using m } \\
\text { and using lo }\end{array}$ & $\begin{array}{l}11 \cdot 0 \\
16 \cdot 4 \\
20 \cdot 5 \\
22 \cdot 3 \\
30 \cdot 2 \\
\\
\text { p value) } \\
\text { iedian ( } \mathrm{p} \text { value) }\end{array}$ & $\begin{array}{l}1 \cdot 00 \\
1 \cdot 1 \\
1.04 \\
1 \cdot 29 \\
1 \cdot 19 \\
0.04 \\
0.08 \\
0.05\end{array}$ & $\begin{array}{l}1 \cdot 00 \\
1 \cdot 19 \\
1 \cdot 12 \\
1 \cdot 25 \\
1 \cdot 16 \\
0 \cdot 21 \\
0 \cdot 17 \\
0 \cdot 10\end{array}$ & $\begin{array}{l}1 \cdot 00 \\
1.36 \\
1 \cdot 23 \\
1.51 \\
1 \cdot 24 \\
0.003 \\
0.07 \\
0.02\end{array}$ & $\begin{array}{l}1 \cdot 00 \\
1.36 \\
1.34 \\
1.48 \\
1 \cdot 20 \\
0.006 \\
0 \cdot 14 \\
0.04\end{array}$ & $\begin{array}{l}1.00 \\
0.99 \\
1.10 \\
0.89 \\
0.79 \\
0.38\end{array}$ & $\begin{array}{l}1.00 \\
1.01 \\
1.12 \\
0.90 \\
0.80 \\
0 \cdot 36\end{array}$ & $\begin{array}{l}1.00 \\
0.98 \\
1.08 \\
0.98 \\
0.88 \\
0.58\end{array}$ & $\begin{array}{l}1.00 \\
0.99 \\
1.09 \\
0.98 \\
0.89 \\
0.56\end{array}$ \\
\hline
\end{tabular}

\begin{tabular}{|c|c|c|c|c|c|c|c|c|c|c|}
\hline \multicolumn{3}{|c|}{$\mathrm{SO}_{2}$ exposure group $(n=9042)$} & \multicolumn{8}{|c|}{ Odds ratio for respiratory symptoms } \\
\hline$n$ & Range & Median & $\begin{array}{l}\text { Cough } \\
*\end{array}$ & $* *$ & $\underset{*}{\text { Phlegm }}$ & $* *$ & $\begin{array}{l}\text { Whee } \\
{ }^{2}\end{array}$ & $3 *$ & \multicolumn{2}{|c|}{$\begin{array}{l}\text { Wheeze since } 16 \\
* *\end{array}$} \\
\hline $\begin{array}{l}1723 \\
1661 \\
1907 \\
1264 \\
2487 \\
\text { Test fo }\end{array}$ & $\begin{array}{r}7 \cdot 0-36 \cdot 4 \\
36 \cdot 7-42 \cdot 7 \\
43 \cdot 0-50 \cdot 5 \\
52 \cdot 0-59 \cdot 3 \\
60 \cdot 9-87 \cdot 7 \\
\text { neity (p val }\end{array}$ & $\begin{array}{l}30 \cdot 7 \\
40 \cdot 8 \\
47 \cdot 0 \\
53 \cdot 5 \\
61 \cdot 5\end{array}$ & $\begin{array}{l}1 \cdot 0 \\
1.21 \\
0.97 \\
1.01 \\
1.00 \\
0 \cdot 12\end{array}$ & $\begin{array}{l}1.0 \\
1.21 \\
0.96 \\
0.99 \\
1.03 \\
0.16\end{array}$ & $\begin{array}{l}1 \cdot 0 \\
1 \cdot 15 \\
0.95 \\
1 \cdot 12 \\
1.00 \\
0.34\end{array}$ & $\begin{array}{l}1.0 \\
1.15 \\
0.94 \\
1 \cdot 12 \\
1.03 \\
0.37\end{array}$ & $\begin{array}{l}1.0 \\
1 \cdot 10 \\
0.93 \\
1.24 \\
1.10 \\
0.54\end{array}$ & $\begin{array}{l}1.0 \\
1.09 \\
0.94 \\
1.25 \\
1.10 \\
0.56\end{array}$ & $\begin{array}{l}1 \cdot 0 \\
1.07 \\
1.0 \\
1 \cdot 10 \\
1.02 \\
0.91\end{array}$ & $\begin{array}{l}1.0 \\
1.06 \\
1.00 \\
1 \cdot 10 \\
1.10 \\
0.93\end{array}$ \\
\hline
\end{tabular}

* Unadjusted odds ratio.

** Adjusted for smoking, sex, and social class.

all those within a county has the advantage that most of the subjects are likely to spend most of their time within the area. Averaging pollution measures by county gave sufficient variation to do an epidemiological analysis. However, there was also variability between monitors within counties, and by averaging these real effects may have been masked. Because all the population is exposed to air pollution to a varying extent, any effect of pollution is harder to detect and imprecise estimates of exposure will tend to bias results to the null - that is, to underestimate effects from pollution. Thus, any bias in the allocation of exposure measures here is likely to result in effects of air pollution being underestimated rather than overestimated.

Past cross sectional studies have shown a relationship between ambient air pollution levels and respiratory symptoms. In 1966 a study of school children in Sheffield showed different prevalences of respiratory illnesses in different areas of the city. ${ }^{8}$ The major difference between areas was in the level of air pollution, and the prevalence of respiratory illness was more influenced by area than by social class, number of children in the house, or sharing of bedrooms. Follow up four years later showed that the prevalence of illness had fallen in all areas in line with falls in pollution levels, ${ }^{9}$ and indicated that pollution was no longer a cause of symptoms. Neither of these studies allowed for exposure to smoking in the home. A national study in 1975 found an association between annual mean levels of smoke and prevalence of respiratory illness in children which appeared to be independent of parental smoking. ${ }^{6}$ However, because the association was at lower levels of smoke $\left(8-51 \mu \mathrm{g} / \mathrm{m}^{3}\right)$ than reported previously, it was thought unlikely to be causal and instead attributed to either chronic effects of past higher levels or some other characteristic of polluted areas.

Recent evidence from the USA supports an association between smoke levels and health effects, although the pattern of pollutants there is different from that seen in the UK. A study of children in six cities in the USA found an effect of total particulates on respiratory symptoms. ${ }^{12}$

Cross sectional studies in adults have shown similar results. Both chronic respiratory symptoms ${ }^{1314}$ and lung function ${ }^{15}$ in adults in the USA were related to levels of total particulates.

In the UK a study of an adult cohort found that respiratory symptoms (phlegm, lower respiratory illness, asthma/wheeze, and peak expiratory flow rate) were not related to $\mathrm{SO}_{2}$ exposure in adulthood, but that both lower respiratory disease and asthma/wheeze in adulthood were significantly related to pollution exposure in childhood as measured by domestic coal consumption. ${ }^{16}$ The effect of adult exposure to smoke was not studied.

Our study suggests that smoke pollution was still a cause of chronic respiratory symptoms in 1981, with an effect on prevalence at concentrations comparable to current ambient levels. In 1991 the annual mean smoke level for each county ranged from 3.4 to $26.5 \mu \mathrm{g} / \mathrm{m}^{3}$ (mean 13.4). This range spans all but the last exposure group used here. These levels are all within the current EC guideline of $35-51 \mu \mathrm{g} /$ $\mathrm{m}^{3}$ annual smoke level. No effect of pollution on the prevalence of wheeze symptoms was found, and there was no evidence from this study that wheezy individuals are particularly susceptible to the effects of ambient air pollution.

Recent evidence from the USA supports our finding that particulate pollution may be more important than $\mathrm{SO}_{2}{ }^{17}$

The nature of the relationship is harder to determine. Time series analysis of the relationship between daily changes in smoke levels and mortality suggests that there is a non-linear relationship which is steeper at lower levels, similar to the relationship we found but at higher levels of smoke. ${ }^{10}$ In contrast, geographical analysis of the effect of total particles suggests an increasing effect on lung function with increasing levels of pollution. ${ }^{18}$ 
The relationship between childhood pollution exposure and adult respiratory symptoms ${ }^{16}$ raises the possibility that the association we found may be a residual effect due to exposure in childhood rather than to present exposure. However, unlike Mann et al, we did find significant associations with current ambient pollution levels. Further study of the childhood exposure of the NCDS cohort is planned and may clarify this issue. The cohort were contacted again in 1991 (at age 33), but the paucity of pollution measures available at that time may restrict the scope for further geographical analyses of respiratory symptoms in relation to current pollution levels.

In conclusion, we found that low ambient levels of particulate pollution were associated with a decreased prevalence of phlegm symptoms in young adults in the UK in 1981. The causal interpretation of these findings would be aided by further studies which can control for a wider range of potential confounders or which assess childhood exposure.

The authors thank Colin Gillham at Warren Spring Laboratory for supplying the air pollution data.

1 Logan WPD. Mortality in the London fog incident, 1952 Lancet 1953;i:336-8.

2 Quality of Urban Air Review Group. Urban air quality in the United Kingdom. London: Department of the Enthe United Kingdom.

3 Gardner MJ, Crawford MD, Morris JN. Patterns of mortality in middle and early old age in the county boroughs of England and Wales. Br F Prev Soc Med 1969;23:133-40.

4 Lawther PJ, Waller RE, Henderson M. Air pollution and exacerbations of bronchitis. Thorax 1970;25:525-39.

5 Chinn S, Florey CV, Baldwin IG, Gorgol M. The relation of mortality in England and Wales 1969-73 to measurements of air pollution. $\mathcal{F}$ Epidemiol Commmunity Health 1981;35:174-9.

6 Melia RJW, Florey CD, Swan AV. Respiratory illness in British schoolchildren and atmospheric smoke and sulphu dioxide 1973-7. I: Cross-sectional findings. $\mathcal{f}$ Epidemio Community Health 1981;35:161-7.

7 Melia RJW, Florey CD, Chinn S. Respiratory illness in British schoolchildren and atmospheric smoke and sulphur dioxide 1973-7. II: Longitudinal findings. $₹$ Epidemiol Community Health 1981;35:168-73.

8 Lunn JE, Knowelden J, Handyside AJ. Patterns of respiratory illness in Sheffield infant schoolchildren. $\mathrm{Br} \mathcal{F}$ Prevent Social Med 1967;21:7-16.

9 Lunn JE, Knowelden J, Roe JW. Patterns of respiratory illness in Sheffield junior schoolchildren. A follow-up study. Br $\mathcal{F}$ Prevent Social Med 1970;24:223-8.

10 Schwartz J, Marcus A. Mortality and air pollution in London: a time series analysis. Am f Epidemiol 1990;131: 185-94.

11 Walters S, Griffiths RK, Ayres JG. Temporal association between hospital admissions for asthma in Birmingham and ambient levels of sulphur dioxide and smoke. Thorax 1994;49:133-40.

12 Ware JH, Ferris BG Jr, Dockery DW, Spengler JD, Stram DO, Speizer FE. Effects of ambient sulfur oxides and suspended particles on respiratory health of preadolescen children. Am Rev Respir Dis 1986;133:834-42.

13 Euler GL, Abbey DE, Magie AR, Hodgkin JE. Chronic obstructive pulmonary disease symptom effects of longterm cumulative exposure to ambient levels of total suspended particulates and sulfur dioxide in California Seventh-Day Adventist residents. Arch Environ Health 1987;42:213-22.

14 Abbey DE, Mills PK, Petersen FF, Beeson WL. Long-term ambient concentrations of total suspended particulates and oxidants as related to incidence of chronic disease in California Seventh-Day Adventists. Environ Health Perspect 1991;94:43-50.

15 Chestnut LG, Schwartz J, Savitz DA, Burchfiel CM. Pulmonary function and ambient particulate matter: epidemiological evidence from NHANES I. Arch Environ Health 1991;46:135-44

16 Mann SL, Wadsworth MEJ, Colley JRT. Accumulation of factors influencing respiratory illness in members of a national birth cohort and their offspring. $f$ Epidemiol Community Health 1992;46:286-92.

17 Schwartz J. Particulate air pollution and daily mortality: synthesis. Public Health Rev 1991;19:39-60.

18 Schwartz J. Lung function and chronic exposure to air pollution: a cross-sectional analysis of NHANES II. Environ Res 1989;50:309-21. 